\title{
Trace element bioaccumulation in grey seals Halichoerus grypus from the Faroe Islands
}

\author{
P. Bustamante ${ }^{1, *}$, C. F. Morales ${ }^{1}$, B. Mikkelsen ${ }^{2}$, M. Dam ${ }^{3}$, F. Caurant ${ }^{1}$ \\ ${ }^{1}$ Laboratoire de Biologie et Environnement Marins, FRE 2727 du CNRS, Université de La Rochelle, 22 Avenue Michel \\ Crépeau, 17042 La Rochelle Cedex, France \\ ${ }^{2}$ Museum of Natural History, Zoology Department, 100 Tórshavn, Faroe Islands \\ ${ }^{3}$ Food and Environmental Agency, 100 Tórshavn, Faroe Islands
}

\begin{abstract}
Grey seals Halichoerus grypus were sampled in the Faroe Islands archipelago during the summers of 1993 to 1995. Concentrations of $\mathrm{Cd}, \mathrm{Cu}, \mathrm{Hg}$, Se and $\mathrm{Zn}$ were measured in the liver, kidney and muscle of 68 seals. All elements except $Z n$ exhibited lowest concentrations in the muscle. The liver contained the highest concentrations of $\mathrm{Cu}, \mathrm{Hg}$, Se and $\mathrm{Zn}$, while the kidney contained the highest $\mathrm{Cd}$ concentrations. However, trace element concentrations within the tissues were influenced by sex and age. Thus, females had clearly higher Cd concentrations than males. Age was the most important factor influencing the concentration of $\mathrm{Cd}, \mathrm{Hg}$ and Se in the liver, and of $\mathrm{Cd}$ and $\mathrm{Hg}$ in the kidney. A strong positive correlation between $\mathrm{Cd}, \mathrm{Hg}$ and $\mathrm{Zn}$ in the kidney suggests the presence of a detoxification process involving metallothionein proteins. Similarly, a strong positive correlation between $\mathrm{Hg}$ and Se and a molecular Hg:Se ratio close to 1 in the liver suggests a demethylation process leading to the formation of mercuric selenide granules. High $\mathrm{Hg}$ concentrations could be related to fish consumption by the grey seal, but a piscivorous diet could not be responsible for the very high Cd concentrations. This suggests that the seals' diet changes during the year, and may include a significant proportion of cephalopods in seasons other than summer. Finally very high Cd concentrations in grey seal tissues compared to other grey seal populations also suggest that the Faroe Islands are subject to sub-arctic influences.
\end{abstract}

KEY WORDS: Heavy metals $\cdot$ Distribution $\cdot$ Detoxification $\cdot$ Marine mammals $\cdot$ Pinnipeds $\cdot$ Sub-arctic Resale or republication not permitted without written consent of the publisher

\section{INTRODUCTION}

Situated in the Northeast Atlantic Ocean, the Faroe Islands are relatively far from major sources of anthropogenic pollution. Nevertheless, marine top predators from this area, such as the long-finned pilot whale Globicephala melas or the white-sided dolphin Lagenorhyncus acutus, exhibit cadmium (Cd) and mercury (Hg) concentrations in their tissues (Julshamn et al. 1987, Caurant et al. 1994, Dam 2001, Gallien et al. 2001) much higher than those reported for individuals from temperate areas which are subject to significant pollution from human activities (Mackey et al. 1995, Law et al. 2001). In fact, toxic metals in top marine predators from the Faroe Islands often reach the threshold level at which metabolic disorders appear in humans (Nogawa 1984). However, such effects are difficult to detect in wild animals such as marine mammals. Recently, Gallien et al. (2001) investigated cellular alterations in relation to $\mathrm{Cd}$ concentrations in the kidney of white-sided dolphins from the Faroe Islands. Their study described calcium phosphate granules in this organ which may have resulted from an effective detoxification process of $\mathrm{Cd}$, and might affect the functioning of the kidney. $\mathrm{Cd}$ can also be detoxified by proteins such as ferritin or metallothionein that regulate essential elements (e.g. $\mathrm{Cu}$ or $\mathrm{Zn}$ ) (Das et al. 2000). In regard to $\mathrm{Hg}$, other processes are involved in its co-precipitation with selenium that produces non-toxic mineral granules of tiemannite (Martoja \& Berry 1980, Nigro \& Leonzio 1996). 
Top marine predators are mainly exposed to trace elements through their food (Aguilar et al. 1999). Thus, a marine mammal with a specialised diet is exposed either to very small or to very large amounts of toxic elements in its prey. For example, very high Cd concentrations in the kidney of pilot whales from the Faroe Islands have been related to their teutophageous diet (Caurant \& Amiard-Triquet 1995, Bustamante et al. 1998a), and lactating pilot whales contain higher Hg concentrations, due to an increase in the proportion of fishes in their diet during the nursing period, since fishes are more energetically valuable than cephalopods (Caurant et al. 1994). In accordance with these conclusions, piscivorous marine mammals such as seals would be expected to have high $\mathrm{Hg}$ and low $\mathrm{Cd}$ concentrations in their tissues.

This study determined the concentration and distribution of 5 trace elements, $\mathrm{Cd}, \mathrm{Cu}, \mathrm{Hg}$, Se and $\mathrm{Zn}$, in a piscivorous marine mammal species from the Faroe Islands, the grey seal Halichoerus grypus. The primary objectives of this work were to investigate the influence of biological (sex, maturity stage and age), ecological (diet) and geographical factors on the bioaccumulation of these trace elements. Particular attention was paid to interactions between the toxic elements $\mathrm{Cd}$ and $\mathrm{Hg}$, and the essential elements $\mathrm{Cu}$, Se and $\mathrm{Zn}$. Also, the trace-element concentrations in the grey seal were compared to those in other seal species and to grey seals from other areas.

Fig. 1. Faroe Islands, showing number and positions of grey seals sampled in summers of period 1993-1995

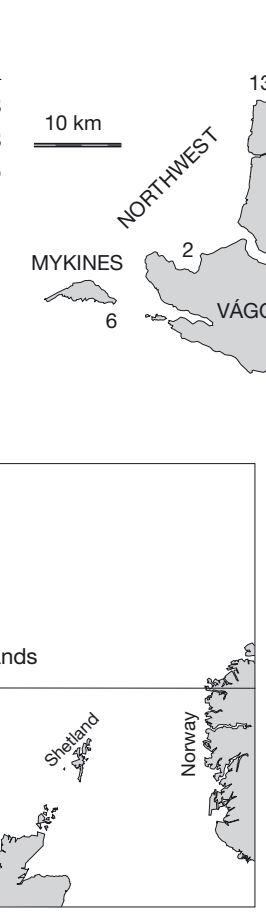

$7^{\circ} \mathrm{W}$

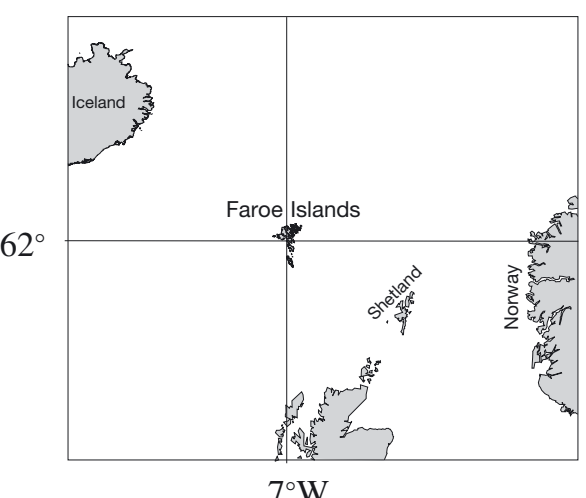

\section{MATERIALS AND METHODS}

Sampling. During the summers of 1993 to 1995 , 68 grey seals were caught off the Faroe Islands (Fig. 1), in a co-operative study by the Museum of Natural History of the Faroe Islands and the Norwegian Institute of Fisheries and Aquaculture, with the aim of studying the diet of this poorly investigated population (Mikkelsen et al. 2002). Organs and tissues were sampled for metallic and organic contaminant investigations (Dam 2001). Samples for trace element analysis, i.e. the liver, kidney and muscle, were stored at $-20^{\circ} \mathrm{C}$ in individual plastic bags until use. Teeth were examined to determine age. Biological parameters (length, weight, blubber thickness, and age) for each sex and maturity stage are given in Table 1.

Analytical procedure. All equipment used in the sample processing was cleaned, and subsequently decontaminated for $24 \mathrm{~h}$ in a solution comprised of $35 \mathrm{ml} \mathrm{HNO}_{3}(65 \%)$ and $50 \mathrm{ml} \mathrm{HCl}(36 \%)$ to $1 \mathrm{l}$ of MilliRo quality water.

Fresh samples were freeze-dried and ground to powder. The mean ratio between wet weight and dry weight was $\sim 3.4$ for liver and muscle, and 4.1 for the kidney. We digested 2 aliquots of approx. $200 \mathrm{mg}$ of each homogenised dry sample with $3.5 \mathrm{ml}$ of $65 \%$ $\mathrm{HNO}_{3}$ at $60^{\circ} \mathrm{C}$ for $3 \mathrm{~d}$. The digested contents were then diluted to $10 \mathrm{ml}$ in Milli-Q quality water. $\mathrm{Cd}, \mathrm{Cu}$, Se and Zn content was assayed using a flame and graphite furnace atomic-absorption spectrophotometer (Varian 250 Plus) with deuterium background correction.

For $\mathrm{Hg}$ measurements, aliquots ranging from 0.5 to $10 \mathrm{mg}$ of dried material were analysed directly for total $\mathrm{Hg}$ in an advanced mercury analyser spectrophotometer (Altec AMA 254). Hg determination involved evaporation of $\mathrm{Hg}$ by progressive heating to $800^{\circ} \mathrm{C}$ under oxygen atmosphere for $3 \mathrm{~min}$, and subsequent amalgamation on a gold net. The net was subsequently heated to liberate the collected mercury and measured by UV atomic-absorption spectrophotometry.

Analytical accuracy was assessed using dogfish liver DOLT-2 (NRCC) and dogfish muscle DORM-2 (NRCC) as reference materials. Analyses were also validated by international intercalibration methods (e.g. Coquery et al. 2000). The standards were treated and analysed under the same conditions as the seal samples. Results were in good agreement with the certified values, and recoveries of the elements ranged from 93 to $105 \%$. 
Table 1. Halichoerus grypus. Biological characteristics of individuals sampled in Faroe Islands in summers of the period 1993 to 1995 . N: number of individuals

\begin{tabular}{|c|c|c|c|c|c|}
\hline Sexual maturity & $\mathrm{N}$ & $\begin{array}{l}\text { Length } \\
(\mathrm{cm})\end{array}$ & $\begin{array}{l}\text { Weight } \\
(\mathrm{kg})\end{array}$ & $\begin{array}{l}\text { Dorsal blubber thickness } \\
\qquad(\mathrm{mm})\end{array}$ & $\begin{array}{c}\text { Age } \\
(\mathrm{yr})\end{array}$ \\
\hline \multicolumn{6}{|l|}{ Male } \\
\hline Mature & 4 & $212.0 \pm 11.9$ & $229.3 \pm 68.4$ & $35.0 \pm 10.0$ & $17.0 \pm 5.2$ \\
\hline Immature & 18 & $136.5 \pm 15.7$ & $56.8 \pm 20.8$ & $22.1 \pm 4.7$ & $1.9 \pm 1.3$ \\
\hline Total & 22 & $150.3 \pm 33.3$ & $89.6 \pm 76.6$ & $24.9 \pm 7.7$ & $4.6 \pm 6.4$ \\
\hline \multicolumn{6}{|l|}{ Female } \\
\hline Mature & 23 & $176.4 \pm 8.5$ & $152.0 \pm 20.8$ & $39.7 \pm 8.5$ & $14.3 \pm 4.5$ \\
\hline Immature & 23 & $133.7 \pm 10.5$ & $49.4 \pm 11.4$ & $22.6 \pm 4.0$ & $2.3 \pm 1.1$ \\
\hline Total & 46 & $154.6 \pm 23.6$ & $99.6 \pm 54.4$ & $31.1 \pm 11.1$ & $8.3 \pm 6.9$ \\
\hline Total & 68 & $153.2 \pm 27.0$ & $96.4 \pm 61.9$ & $29.1 \pm 10.5$ & $7.1 \pm 6.9$ \\
\hline
\end{tabular}

Detection limits ( $\mu \mathrm{g} \mathrm{g}^{-1}$ dry wt) were 0.004 for $\mathrm{Cd}, 0.5$ for $\mathrm{Cu}, 3$ for $\mathrm{Zn}, 0.8$ for Se, and 0.005 for total $\mathrm{Hg}$. All trace element concentrations in seal tissues are reported as $\mu \mathrm{g} \mathrm{g}^{-1}$ wet wt (WW).

Statistical analysis. Differences in concentrations of trace elements between species were tested by 1-way ANOVA (after log-transformation of data when necessary) followed by a Tukey multiple-comparison test with MINITAB 13.1 software. The hypothesis of normal distribution was tested with the Anderson-Darling test and equality of variance by the Bartlett test. The significance level for statistical analyses was always set at $\alpha=0.05$.

\section{RESULTS}

\section{Levels of trace elements and organotropism}

$\mathrm{Cd}, \mathrm{Cu}, \mathrm{Hg}$, Se and $\mathrm{Zn}$ concentrations in the liver, kidney and muscle for each sex and maturity stage are presented in Table 2. Cd and Hg concentrations varied greatly among tissues. The kidney exhibited the highest Cd concentrations $\left(15.8 \pm 24.6 \mu \mathrm{g} \mathrm{g}^{-1} \mathrm{WW}\right)$, followed by the liver $\left(5.06 \pm 8.63 \mu \mathrm{g} \mathrm{g}^{-1} \mathrm{WW}\right)$, with the muscle containing $\mathrm{Cd}$ concentrations several orders of magnitude lower $\left(0.05 \pm 0.14 \mu g^{-1} \mathrm{WW}\right)$ (Table 2). As expected for a toxic element, the coefficients of variation for Cd were large in all tissues, i.e. $155 \%$ for the kidney, $170 \%$ for the liver and $280 \%$ for muscle. Among the 3 tissues analysed, the liver exhibited the highest $\mathrm{Hg}$ concentrations $\left(59.7 \pm 70.4 \mathrm{\mu g} \mathrm{g}^{-1} \mathrm{WW}\right)$ followed by the kidney $\left(2.93 \pm 2.47 \mathrm{\mu g} \mathrm{g}^{-1} \mathrm{WW}\right)$ and muscle $\left(0.74 \pm 0.65 \mu \mathrm{g} \mathrm{g}^{-1} \mathrm{WW}\right)$ (Table 2$)$. The coefficients of variation for $\mathrm{Hg}$ were relatively high, particularly for the liver $(118 \%)$ but also for the kidney and muscle (84 and $88 \%$, respectively). The liver also exhibited the highest Se concentrations $\left(23.0 \pm 26.2 \mu \mathrm{g} \mathrm{g}^{-1} \mathrm{WW}\right)$, followed by the kidney $\left(5.47 \pm 1.43 \mu \mathrm{g} \mathrm{g}^{-1} \mathrm{WW}\right)$ and mus- cle $\left(0.27 \pm 0.10 \mu \mathrm{g} \mathrm{g}^{-1} \mathrm{WW}\right)$. For Se, the coefficients of variation were lower than $40 \%$ in the kidney and muscle but higher than $100 \%$ in the liver.

The liver exhibited the highest $\mathrm{Cu}$ concentrations $\left(38.7 \pm 18.1 \mu \mathrm{g} \mathrm{g}^{-1} \mathrm{WW}\right)$, while concentrations were relatively low in the kidney and muscle $(3.1 \pm 0.5$ and $1.5 \pm 0.3 \mu \mathrm{g} \mathrm{g}^{-1} \mathrm{WW}$, respectively). As expected for an essential element, the coefficients of variation were low for $\mathrm{Cu}$, i.e. 15, 25 and $47 \%$ in the kidney, muscle and liver, respectively. The liver also showed the highest $\mathrm{Zn}$ concentrations (57 $\pm 10 \mu \mathrm{g} \mathrm{g}^{-1} \mathrm{WW}$ ), followed by the muscle $\left(41 \pm 9 \mu \mathrm{g} \mathrm{g}^{-1} \mathrm{WW}\right)$ and the kidney (27 $\pm 7 \mathrm{\mu g} \mathrm{g}^{-1} \mathrm{WW}$ ). For $\mathrm{Zn}$, the coefficients of variation were lower than $30 \%$ in all 3 tissues analysed.

\section{Influence of gender}

Cd was the only element exhibiting a significant difference between sexes. Thus, Cd concentrations in the kidney were significantly higher $(p<0.001)$ in adult females than in adult males (i.e. $40.8 \pm 28.8$ and $10.5 \pm$ $4.69 \mu \mathrm{g} \mathrm{g}^{-1} \mathrm{WW}$, respectively), resulting from 5 times higher $\mathrm{Cd}$ accumulation rates in females (Fig. 2). In the liver, males exhibited significantly $(p<0.001)$ lower $\mathrm{Cd}$ concentrations of $1.76 \pm 0.27 \mu \mathrm{g} \mathrm{Cd} \mathrm{g}{ }^{-1} \mathrm{WW}$, while females exhibited mean concentrations of $13.2 \pm$ $11.0 \mu \mathrm{g} \mathrm{g}^{-1} \mathrm{WW}$, resulting from $\mathrm{Cd}$ accumulation rates that were 10 times higher than in males (Fig. 2).

No other significant differences between sexes were found for the other elements in grey seal tissues.

\section{Influence of maturity stage and age}

Cd concentrations in the 3 tissues of mature individuals were higher than those in immature individuals $(F=47.40, \mathrm{p}<0.001)$ (Table 2). Moreover, Cd was significantly correlated with age in the kidney and 
Table 2. Halichoerus grypus. Mean $\pm \mathrm{SD}$ and range of trace element concentrations ( $\mu g \mathrm{~g}^{-1} \mathrm{WW}$ ) in liver, kidney and muscle. $\mathrm{N}$ : number of individuals

\begin{tabular}{|c|c|c|c|c|c|c|c|c|c|c|c|}
\hline \multirow[t]{2}{*}{ Tissue } & \multirow[b]{2}{*}{$\mathrm{N}$} & \multicolumn{2}{|c|}{$\mathrm{Cd}$} & \multicolumn{2}{|c|}{$\mathrm{Cu}$} & \multicolumn{2}{|c|}{$\mathrm{Hg}$} & \multicolumn{2}{|c|}{$\mathrm{Se}$} & \multicolumn{2}{|l|}{$\mathrm{Zn}$} \\
\hline & & Mean \pm SD & Range & Mean \pm SD & Range & Mean $\pm \mathrm{SD}$ & Range & Mean $\pm \mathrm{SD}$ & Range & Mean \pm SD & Range \\
\hline \multicolumn{12}{|l|}{ Liver } \\
\hline \multicolumn{12}{|l|}{ Male } \\
\hline Mature & 4 & $1.76 \pm 0.27$ & $1.50-2.09$ & $31.2 \pm 8.1$ & $23.8-41.8$ & $123 \pm 70.9$ & $46.4-199$ & $41.2 \pm 24.7$ & $18.8-53.1$ & $62 \pm 14$ & $50-76$ \\
\hline Immature & 18 & $0.59 \pm 0.80$ & $0.06-3.61$ & $29.6 \pm 18.2$ & $5.5-79.6$ & $10.3 \pm 15.9$ & $1.56-65.4$ & $4.69 \pm 5.63$ & $1.43-23.7$ & $53 \pm 8$ & $30-63$ \\
\hline \multicolumn{12}{|l|}{ Female } \\
\hline Mature & 23 & $13.2 \pm 11.0$ & $2.29-51.9$ & $51.6 \pm 16.3$ & $28.3-85.3$ & $133 \pm 58.0$ & $34.2-238$ & $50.6 \pm 22.8$ & $13.5-99.9$ & $60 \pm 8$ & $46-75$ \\
\hline Immature & 23 & $1.04 \pm 1.07$ & $0.15-4.05$ & $34.4 \pm 14.0$ & $7.2-61.1$ & $14.0 \pm 18.7$ & $1.13-90.1$ & $6.47 \pm 7.15$ & $1.17-35.6$ & $56 \pm 10$ & $31-75$ \\
\hline Total & 68 & $5.06 \pm 8.63$ & $0.06-51.9$ & $38.7 \pm 18.1$ & $5.5-85.3$ & $59.7 \pm 70.4$ & $1.13-238$ & $23.0 \pm 26.2$ & $1.17-99.9$ & $57 \pm 10$ & $30-76$ \\
\hline \multicolumn{12}{|l|}{ Kidney } \\
\hline \multicolumn{12}{|l|}{ Male } \\
\hline Mature & 4 & $10.5 \pm 4.69$ & $6.30-15.3$ & $2.5 \pm 0.4$ & $2.0-2.9$ & $7.89 \pm 5.86$ & $2.85-15.9$ & $6.49 \pm 2.22$ & $4.02-8.95$ & $29 \pm 4$ & $23-31$ \\
\hline Immature & 18 & $2.07 \pm 1.72$ & $0.39-7.43$ & $3.3 \pm 0.5$ & $2.6-4.6$ & $1.77 \pm 1.22$ & $0.41-4.53$ & $5.10 \pm 1.24$ & $2.72-6.87$ & $23 \pm 2$ & $18-28$ \\
\hline \multicolumn{12}{|l|}{ Female } \\
\hline Mature & 23 & $40.8 \pm 28.8$ & $8.91-155$ & $3.0 \pm 0.4$ & $2.2-3.9$ & $4.49 \pm 1.28$ & $1.63-7.15$ & $5.93 \pm 1.31$ & $3.50-9.42$ & $35 \pm 6$ & $26-53$ \\
\hline Immature & 23 & $2.52 \pm 1.50$ & $0.96-6.23$ & $3.1 \pm 0.4$ & $2.4-3.6$ & $1.41 \pm 0.75$ & $0.61-4.06$ & $5.10 \pm 1.40$ & $2.63-7.15$ & $23 \pm 3$ & $19-28$ \\
\hline Total & 68 & $15.8 \pm 24.6$ & $0.39-155$ & $3.1 \pm 0.5$ & $2.0-4.6$ & $2.93 \pm 2.47$ & $0.41-15.9$ & $5.47 \pm 1.43$ & $2.63-9.42$ & $27 \pm 7$ & $18-53$ \\
\hline \multicolumn{12}{|l|}{ Muscle } \\
\hline \multicolumn{12}{|l|}{ Male } \\
\hline Mature & 4 & $0.03 \pm 0.02$ & $0.01-0.05$ & $1.1 \pm 0.2$ & $1.0-1.2$ & $1.99 \pm 1.86$ & $0.59-4.61$ & $0.27 \pm 0.07$ & $0.18-0.34$ & $33 \pm 9$ & $25-44$ \\
\hline Immature & 17 & $0.01 \pm 0.01$ & $<0.01-0.04$ & $1.7 \pm 0.3$ & $1.4-2.4$ & $0.53 \pm 0.28$ & $0.18-1.21$ & $0.29 \pm 0.14$ & $0.08-0.50$ & $42 \pm 9$ & $24-57$ \\
\hline \multicolumn{12}{|l|}{ Female } \\
\hline Mature & 23 & $0.12 \pm 0.23$ & $0.01-1.13$ & $1.4 \pm 0.3$ & $1.1-1.9$ & $1.00 \pm 0.48$ & $0.31-2.63$ & $0.23 \pm 0.05$ & $0.14-0.36$ & $44 \pm 9$ & $24-53$ \\
\hline Immature & 23 & $0.01 \pm 0.01$ & $<0.01-0.06$ & $1.6 \pm 0.4$ & $1.2-2.9$ & $0.44 \pm 0.21$ & $0.22-1.06$ & $0.29 \pm 0.10$ & $0.11-0.51$ & $40 \pm 8$ & $24-51$ \\
\hline Total & 67 & $0.05 \pm 0.14$ & $<0.01-1.13$ & $1.5 \pm 0.3$ & $1.0-2.9$ & $0.74 \pm 0.65$ & $0.18-4.61$ & $0.27 \pm 0.10$ & $0.08-0.51$ & $41 \pm 9$ & $24-57$ \\
\hline
\end{tabular}

liver (Fig. 2). In the former, the correlation was linear for both males and females $(\mathrm{r}=0.947, \mathrm{p}<0.001 ; \mathrm{r}=$ $0.818, \mathrm{p}<0.001$; respectively). However, the correlation between hepatic $\mathrm{Cd}$ and age fitted a logarithmic pattern for males $(r=0.747, \mathrm{p}<0.001)$ and a linear pattern for females $(r=0.672, p<0.001)$ (Fig. 2).

There were higher $\mathrm{Hg}$ concentrations in the 3 tissues in mature individuals than in immature seals $(F=$ 23.91, p < 0.001). Hepatic and renal Hg concentrations increased linearly with increasing age $(\mathrm{r}=0.882, \mathrm{p}<$ 0.001; $\mathrm{r}=0.733, \mathrm{p}<0.001$; respectively) (Fig. 3).

Hepatic Se concentrations differed significantly $(F=$ 82.48, $\mathrm{p}<0.001)$ between immature $\left(5.69 \pm 6.51 \mathrm{\mu g} \mathrm{g}^{-1}\right.$ WW) and mature individuals of both sexes (49.2 \pm $\left.22.9 \mu \mathrm{g} \mathrm{g}^{-1} \mathrm{WW}\right)$. Se concentrations were correlated with age only in the liver $(r=0.857, p<0.001)$. Furthermore, hepatic $\mathrm{Cu}$ concentrations were significantly lower $(F=6.86, \mathrm{p}<0.002)$ in immature $(32.3 \pm$ $\left.15.9 \mathrm{\mu g} \mathrm{g}^{-1} \mathrm{WW}\right)$ than in mature $\left(48.6 \pm 16.9 \mu \mathrm{g} \mathrm{g}^{-1}\right.$ WW) seals, and renal $\mathrm{Cu}$ concentrations in both sexes were significantly higher $(F=6.02, \mathrm{p}<0.004)$ in immature $\left(3.2 \pm 0.4 \mathrm{\mu g} \mathrm{g}^{-1} \mathrm{WW}\right)$ than in mature $(2.9 \pm 0.5 \mu \mathrm{g}$ $\mathrm{g}^{-1} \mathrm{WW}$ ) seals. However, $\mathrm{Cu}$ concentrations in the tissues of grey seals were not correlated with age.

For both sexes, mature seals had significantly higher
Zn concentrations in the kidney $(F=55.36, \mathrm{p}<0.001)$ than immature individuals $\left(34 \pm 7 \mu^{-1} \mathrm{WW}\right.$ and $23 \pm 3 \mu \mathrm{g} \mathrm{g}^{-1} \mathrm{WW}$, respectively). Therefore, renal $\mathrm{Zn}$ increased linearly with increasing age $(r=0.796, p<$ 0.001). However, $\mathrm{Zn}$ concentrations in the liver and muscle were not correlated with age.

\section{Correlation between elements}

Table 3 shows the correlation between trace elements in the 3 tissues. In the liver, Cd concentrations were correlated to $\mathrm{Hg}$, Se and $\mathrm{Zn}(\mathrm{p}<0.001$, Table 3$)$. $\mathrm{Hg}$ and Se concentrations exhibited a linear relationship for both sexes $(r=0.989, p<0.001)$ (Fig. 5). Thus, the calculated molar ratio between $\mathrm{Hg}$ and Se was also correlated with age $(r=0.642, \mathrm{p}<0.001)$, approached 1 (Fig. 5).

In the kidney, Zn was correlated with Cd ( $\mathrm{r}=0.907$, $\mathrm{p}<0.001)$ and $\mathrm{Hg}(\mathrm{r}=0.698, \mathrm{p}<0.001)$ (Fig. 4). Renal $\mathrm{Hg}$ concentrations were also strongly correlated with Se $(r=0.688, p<0.001)$ and $C d(r=0.773, p<0.001)$ (Fig. 4).

In the muscle, only a negative correlation was found - between $\mathrm{Cu}$ and $\mathrm{Hg}$ (Table 3). 
Males
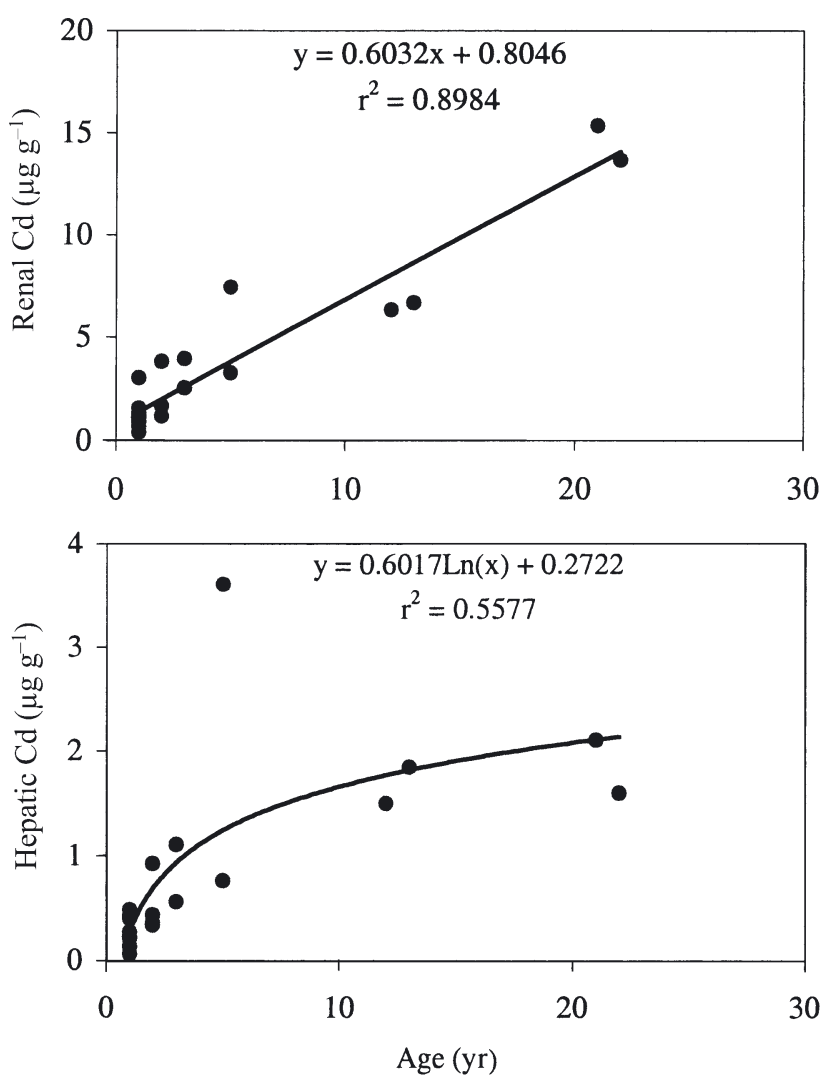

Females
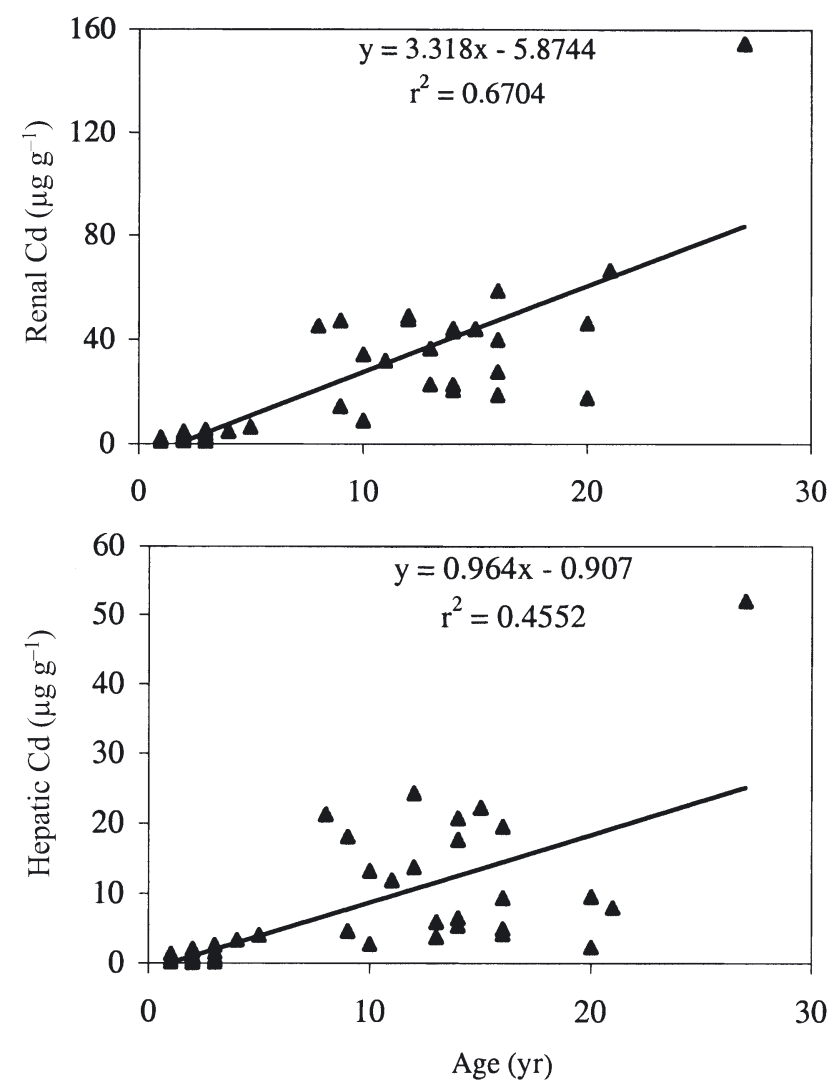

Fig. 2. Halichoerus grypus. Renal and hepatic Cd concentrations ( $\mu \mathrm{g} \mathrm{g}^{-1} \mathrm{WW}$ ) as a function of age in males and females. Note different scales of ordinates


Fig. 3. Halichoerus grypus. Renal and hepatic Hg concentrations ( $\left.\mu \mathrm{g} \mathrm{g}^{-1} \mathrm{WW}\right)$ as a function of age

\section{DISCUSSION}

In contrast to pinniped species, i.e. harp and ringed seals, that are traditionally hunted and which have been extensively studied for trace element and organic compound bioaccumulation (see review by Muir et al. 1992), the grey seal has rarely been investigated, and then often using only a few individuals (Morris et al. 1989, Frank et al. 1992, Law et al. 1992, 1998, Teigen et al. 1999, Dam 2001, Nyman et al. 2002). This is proba- 
Table 3. Halichoerus grypus. Correlation between trace elements in the different tissues. Underlined: $p<0.001$; other: $\mathrm{p}<0.05$

\begin{tabular}{|c|c|c|c|}
\hline Elements & Liver & Kidney & Muscle \\
\hline $\mathrm{Cd}$ & $+\mathrm{Hg}_{1}+\mathrm{Se},+\mathrm{Zn}$ & $+\mathrm{Hg}_{1}+\mathrm{Zn}$ & \\
\hline $\mathrm{Cu}$ & $\overline{+\mathrm{Hg}}, \overline{+\mathrm{Se}}, \overline{+\mathrm{Zn}}$ & $\overline{-\mathrm{Hg}}$ & $-\mathrm{Hg}$ \\
\hline $\mathrm{Hg}$ & $+\mathrm{Cd}, \overline{+\mathrm{Cu}},+\overline{+\mathrm{Se}}$ & $\overline{+\mathrm{Cd}},-\mathrm{Cu}_{1}+\mathrm{Se},+\mathrm{Zn}$ & $-\mathrm{Cu}$ \\
\hline $\mathrm{Se}$ & $\overline{+\mathrm{Cd}},+\mathrm{Cu}, \overline{+\mathrm{Hg}}$ & $\overline{+\mathrm{Hg}}, \overline{ }=$ & \\
\hline $\mathrm{Zn}$ & $\overline{+\mathrm{Cd}}, \overline{+\mathrm{Cu}}$ & $\overline{+\mathrm{Cd}},+\mathrm{Hg}$ & \\
\hline
\end{tabular}

bly because most grey seal populations either live in protected areas or are not traditionally hunted. Generally, only stranded individuals, or those found in fishing by-catches, or individuals killed in small numbers with special authorisation are available for ecotoxicological analyses. Thus, the Faroe Island study of the grey seal diet in this archipelago provided a rare opportunity to investigate the bioaccumulation of trace elements in a presumably healthy marine mammal population.

As in other pinniped species (e.g. Wagemann et al. 1988, Dietz et al. 1996, de Moreno et al. 1997,
Julshamn \& Grahl-Nielsen 2000, Fant et al. 2001), each trace element analysed was mainly concentrated in a specific tissue. Thus, the highest concentrations of $\mathrm{Cu}$, $\mathrm{Hg}$, Se and $\mathrm{Zn}$ were found in the liver, whereas the kidney contained the highest $\mathrm{Cd}$ concentrations (Table 2). However, within a given population, several factors such as sex, reproductive status, age and diet greatly influence the concentration of trace elements within tissues.

In marine mammals, trace elements are mainly incorporated into the body via their food, and thus diet is the main factor determining the trace-element load of a given species (Aguilar et al. 1999). Therefore, intake via food presumably represents the bulk of trace-element intake. Dietary examination of the same individuals used in this study showed that grey seals from the Faroe Islands feed exclusively on fishes during the summer period, with the stomach contents of males and females revealing a similar diet (Mikkelsen et al. 2002). However, the very high $\mathrm{Cd}$ concentrations present in their tissues was not in accordance with a piscivorous diet. Fish consumption would result in very low Cd levels, as most fish species generally contain
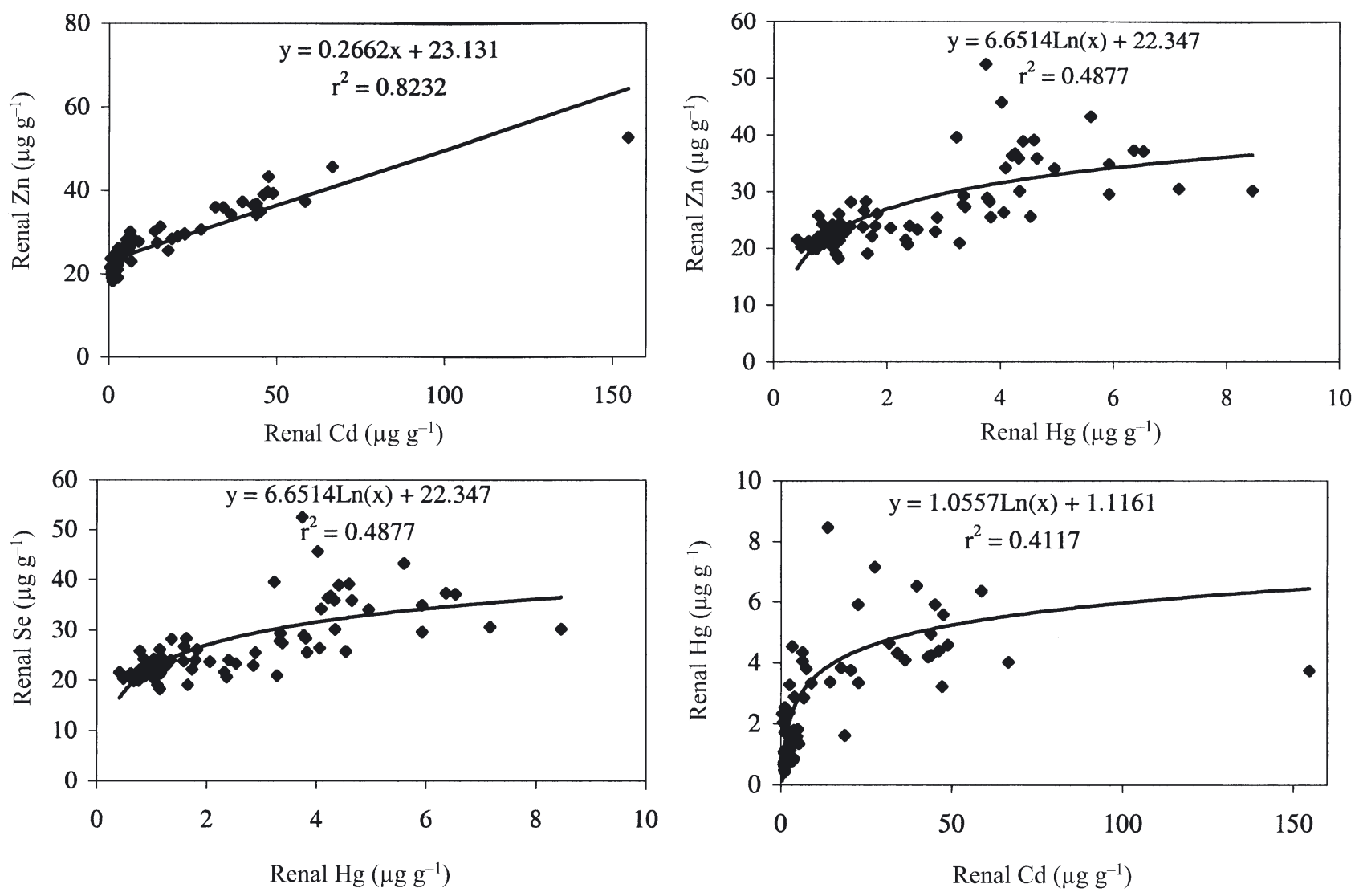

Fig. 4. Halichoerus grypus. Correlation between $\mathrm{Cd}$ and $\mathrm{Zn}$, between $\mathrm{Hg}$ and $\mathrm{Zn}$, between $\mathrm{Hg}$ and Se and between $\mathrm{Cd}$ and $\mathrm{Hg}$ concentrations ( $\left.\mathrm{g} \mathrm{g} \mathrm{g}^{-1} \mathrm{WW}\right)$ in kidney 

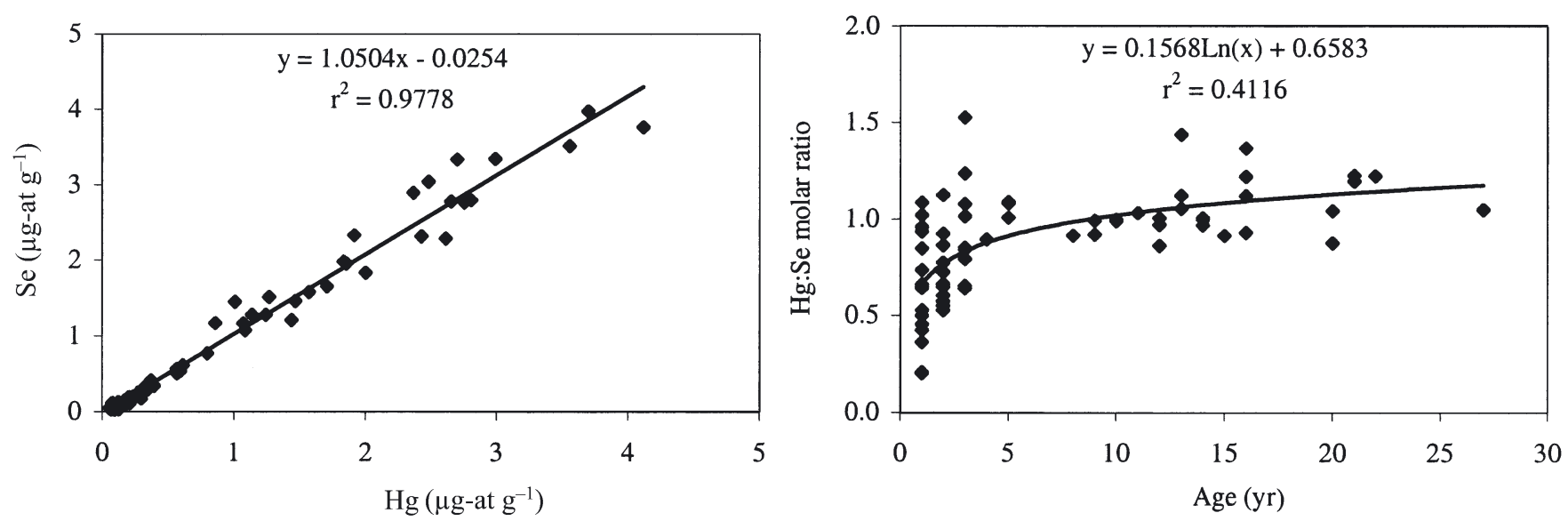

Fig. 5. Halichoerus grypus. Correlation between hepatic $\mathrm{Hg}$ and Se concentrations ( $\mu g$-at $\mathrm{g}^{-1}$ dry wt) and molar Hg:Se as a function of age

relatively low Cd levels (Bustamante et al. 2003). In the light of the present results, it seems likely that the diet of grey seals in Faroese waters changes during the year, and includes a significant proportion of cephalopods, which strongly increases their exposure to $\mathrm{Cd}$ (Bustamante et al. 1998a). In fact, the diet of grey seals in northern temperate waters appears to be very dependent on season (Pierce et al. 1990, 1991, Hammond et al. 1994), and to be very similar to the diet described by Mikkelsen et al. (2002) for Faroe grey seals during the summer. However, in autumn, winter and spring, the grey seals of northern temperate waters increased the proportion of cephalopods in their diet. Such a shift in diet might occur in Faroe grey seals also, and would explain the high $\mathrm{Cd}$ concentrations found in their liver and kidney during the present study.

Although investigation of the grey seal diet in the Faroe Islands revealed no sex-related difference in diet (Mikkelsen et al. 2002), Cd concentrations in the liver and kidney displayed a significant gender-related difference. Thus, females exhibited significantly higher renal and hepatic concentrations than males (Table 2 \& Fig. 1). Nyman et al. (2002) also reported higher $\mathrm{Cd}$ concentrations in the liver and kidney of female grey seals from the Baltic Sea and from Sable Island. Similar gender differences in the Antarctic fur seal Arctocephallus gazella and the Baïkal seal Phoca sibirica were partly explained by different feeding habits of males and females (de Moreno et al. 1997, Watanabe et al. 1998). Such differences in metal concentrations are sometimes attributable to sexual dimorphism (Caurant et al. 1994, Watanabe et al. 1998), and this could be the case here, since grey seal males weigh up to $290 \mathrm{~kg}$, while females do not exceed $191 \mathrm{~kg}$. Moreover, female seals seem to have higher feeding rates than males (essentially because of the energetic cost of reproduction, viz. gestation and lactation) while males drastically reduce their feeding during the mating and moulting seasons. For example, an adult male ringed seal weighing about $70 \mathrm{~kg}$ would ingest 1200 to $1300 \mathrm{~kg}$ food per year, whereas an adult female weighing about $60 \mathrm{~kg}$ would require $1600 \mathrm{~kg}$ per year (Ryg \& Øritsland 1991). Since male and female grey seals feed on the same species, and probably have a similar feeding dimorphism to ringed seals, the uptake of $\mathrm{Cd}$ would be greater for females because of their higher ratios of food ingested:body weight. This also suggests that the transfer of $\mathrm{Cd}$ to the foetus through the placenta or to calves via milk is not an important way of excretion for females. It cannot be excluded that this difference between males and females is associated with a difference in metabolic pathways linked to the hormone cycle, which obviously differs between sexes (Caurant et al. 1994). An increase in trace element concentrations with increasing age was observed for $\mathrm{Cd}$ in the liver and kidney of both sexes, but gender differences in the accumulation rates occurred (Fig. 2). In the liver, the pattern of increasing $\mathrm{Cd}$ concentration with increasing age differed between the sexes, fitting a logarithmic trend only for males. A logarithmic pattern in $\mathrm{Cd}$ accumulation has previously been shown in the liver of the longfinned pilot whale from the Faroe Islands (Caurant et al. 1994). It may represent an equilibrium between the assimilation and excretion of $\mathrm{Cd}$ in the liver similar to that which occurs in humans of $\geq 50 \mathrm{yr}$ of age (Friberg et al. 1974). In grey seals, such equilibrium would appear to occur from 12 yr onwards in males, whereas females accumulate $\mathrm{Cd}$ linearly with age. However, the present samples lacked very old females: the maximum age of our samples was $27 \mathrm{yr}$, whereas grey seals can attain more than 35 yr of age. 
Table 4. Concentrations of renal Cd and hepatic $\mathrm{Hg}\left(\mu \mathrm{g} \mathrm{g}^{-1} \mathrm{WW}\right)$ in various species of pinnipeds sampled in different regions and habitats. -: no data

\begin{tabular}{|c|c|c|c|c|c|c|c|c|}
\hline \multirow{2}{*}{ Region } & \multirow[t]{2}{*}{ Species } & \multicolumn{3}{|c|}{${ }_{\text {Renal Cd }}$} & \multicolumn{3}{|c|}{- Hepatic Hg } & \multirow{2}{*}{ Source } \\
\hline & & $\mathrm{N}$ & Mean $\pm \mathrm{SD}$ & Range & $\mathrm{N}$ & Mean $\pm \mathrm{SD}$ & Range & \\
\hline \multicolumn{9}{|l|}{ Arctic } \\
\hline Greenland Sea & Harp seal & 29 & - & $0.1-101$ & 29 & - & $0.14-7.7$ & $\begin{array}{l}\text { Julshamn \& } \\
\text { Grahl-Nielsen (2000) }\end{array}$ \\
\hline Greenland Sea & Hooded seal & 22 & - & $0.13-207$ & 22 & - & $0.26-179$ & $\begin{array}{l}\text { Julshamn \& } \\
\text { Grahl-Nielsen (2000) }\end{array}$ \\
\hline Arctic Ocean & Harbour seal & - & - & - & 38 & - & $0.2-66$ & Frank et al. (1992 \\
\hline West arctic Canada & Ringed seal & 144 & $21.1 \pm 14.2$ & $0.12-87.1$ & 145 & $32.9 \pm 35.2$ & $0.2-2.2$ & Wagemann et al. (1996) \\
\hline East arctic Canada & Ringed seal & 35 & $47.7 \pm 23.3$ & $8.98-111$ & 115 & $8.3 \pm 7.0$ & $0.4-38.7$ & Wagemann et al. (1996) \\
\hline Eureka (Canada) & Ringed seal & 17 & $15.6 \pm 13.8$ & $0.009-46.3$ & 8 & $26.5 \pm 36.9$ & $0.4-143$ & Wagemann et al. (1996) \\
\hline \multicolumn{9}{|l|}{ Subarctic } \\
\hline Faroe Islands & Grey seal & 68 & $15.8 \pm 24.6$ & $0.39-154.7$ & 68 & $59.7 \pm 70.4$ & $1.13-237.7$ & This study \\
\hline Baltic Sea & Grey seal & 20 & $3.4 \pm 1.7$ & $1.4-7.6$ & 20 & $78 \pm 84$ & $15-348$ & Nyman et al. (2002) \\
\hline Baltic Sea & Grey seal & 19 & - & $0.25-2.72$ & 19 & - & $7.03-92$ & Frank et al. (1992) \\
\hline Sable Island & Grey seal & 20 & $1.8 \pm 1.1$ & $3.0-20$ & 20 & $109 \pm 72$ & $27-278$ & Nyman et al. (2002) \\
\hline Norway Oslofjord & Harbour seal & - & - & - & 28 & 4.1 & $0.1-30$ & Skaare et al. (1990) \\
\hline $\begin{array}{l}\text { Norway southern } \\
\text { coast }\end{array}$ & Harbour seal & - & - & - & 26 & 16 & $0.2-89$ & Skaare et al. (1990) \\
\hline $\begin{array}{l}\text { Norway northern } \\
\text { coast }\end{array}$ & Harbour seal & - & - & - & 17 & 7.9 & $0.4-43$ & Skaare et al. (1990) \\
\hline St. Laurent gulf & Harp seal & 20 & $28 \pm 9$ & $9.5-46.3$ & 20 & $10.4 \pm 8.1$ & $1.3-30.1$ & Wagemann et al. (1988) \\
\hline Baltic Sea & Ringed seal & 20 & - & $0.8-6$ & 20 & 53 & $6.5-124$ & Fant et al. (2001) \\
\hline \multicolumn{9}{|c|}{ Northern temperate waters } \\
\hline Irish Sea & Grey seal & 2 & 2.1 & $1.7-2.5$ & 2 & 0.07 & $0.06-0.08$ & Morris et al. (1989) \\
\hline Irish Sea & Grey seal & - & - & - & 21 & $108 \pm 132$ & $0.5-430$ & Law et al. (1992) \\
\hline Liverpool Bay & Grey seal & - & - & - & 2 & 595 & $330-860$ & Law et al. (1992) \\
\hline Irish Sea & Harbour seal & - & - & - & 13 & $51 \pm 58$ & $1-170$ & Law et al. (1992) \\
\hline \multicolumn{9}{|l|}{ Lakes } \\
\hline Baikal & Baikal seal & 40 & $1.8 \pm 0.8$ & $0.6-3.6$ & 41 & $2.3 \pm 2.6$ & $0.2-9.1$ & Watanabe et al. (1998) \\
\hline
\end{tabular}

$\mathrm{Cu}$ and $\mathrm{Zn}$ concentrations in grey seals appear to be in the same order of magnitude as those reported for other pinniped species, probably because these essential elements are subject to homeostatic regulation in marine mammal tissues (Law 1996). However, Cd, Hg and Se levels in the present study were amongst the highest reported for pinnipeds in the literature. Thus, hepatic Se levels in grey seals from the Faroe Islands varied from 1.17 to $99.9 \mathrm{\mu g} \mathrm{g}^{-1} \mathrm{WW}$ and were comparable to the high hepatic Se concentrations (ranging from 1.30 to $65.3 \mu^{g^{-1}} \mathrm{WW}$ ) in ringed seals from the western Canadian arctic (Wagemann et al. 1996). High Se concentrations in liver have also been reported for grey seals from the Baltic Sea (2.7 to $79.2 \mu \mathrm{g} \mathrm{g}^{-1} \mathrm{WW}$ ) and from Sable Island (9.3 to $83 \mu \mathrm{g} \mathrm{g}^{-1} \mathrm{WW}$ ) (Nyman et al. 2002). Cd and Hg concentrations are globally well documented in seals (Table 4). Generally, seals from polar areas exhibit high levels of renal $\mathrm{Cd}$ and hepatic Hg. Surprisingly for a species largely distributed in temperate waters, grey seals also generally have very high $\mathrm{Hg}$ concentrations in their liver. The present results for grey seals from the Faroe Islands follow this trend, with $\mathrm{Hg}$ concentrations in the liver varying from
1.13 to $238 \mu^{-1} g^{-1}$ WW. As far as Cd is concerned, grey seals from the Faroe Islands appear to be atypical, compared to those from the Baltic Sea or Sable Island (Table 4), displaying Cd concentrations in the kidney comparable to those of seals from the Arctic, and clearly higher $\mathrm{Cd}$ concentrations than grey seals from the Baltic Sea or Sable Island.

In summary, compared to other pinnipeds, particularly those from lower latitudes, renal Cd and hepatic $\mathrm{Hg}$ concentrations in grey seals from the Faroe Islands are among the highest recorded (Table 4). Very high $\mathrm{Hg}$ concentrations in grey seals from the Irish Sea were related to feeding habits in a very contaminated area, Liverpool Bay, where their prey is enriched in $\mathrm{Hg}$ (Law et al. 1992). In the Faroe Islands, no such enrichment by industrial contamination exists. Consequently, the high $\mathrm{Hg}$ concentrations in the tissues of the grey seals must result from high background levels. In contrast, the reasons for the general Cd enrichment recorded in arctic waters remain unclear. Local enrichments have been noted for marine mammal populations throughout the Arctic but such local variations do not explain the phenomenon on a global scale (Wagemann et al. 
1996). Several authors have proposed a phenomenon of $\mathrm{Cd}$ abnormality in polar and subpolar areas that leads to very high $\mathrm{Cd}$ concentrations in many invertebrates and vertebrates (Petri \& Zauke 1993, Bargagli et al. 1996, Bustamante et al. 1998b, Zauke et al. 1999). Such an abnormality seems to occur in the Faroe Islands too. Indeed, similar to polar regions, soluble trace-element concentrations in the seawater appear to be very low in this area (Mart \& Nürnberg 1984), but high $\mathrm{Cd}$ concentrations have been found in the cephalopods Loligo forbesi, Todarodes sagittatus and Eledone cirrhosa (up to $9.06 \pm 3.38 \mu \mathrm{g} \mathrm{g}^{-1} \mathrm{WW}$ ) and in the queen scallop Aequipecten opercularis (6.55 \pm $1.97 \mathrm{\mu g} \mathrm{g}^{-1} \mathrm{WW}$ ) caught around the Faroes archipelago (Bustamante 1998, Bustamante et al. 1998a). Similarly, in coastal waters, the dog-whelk Nucella lapillus and the limpet Patella sp. displayed Cd concentrations of 28 and $10 \mu \mathrm{g} \mathrm{g}^{-1} \mathrm{WW}$, respectively (Dam 2000); and other marine mammal species from the Faroe Islands, i.e. the long-finned pilot whale Globicephala melas and the white-sided dolphin Lagenorhynchus acutus, also had very high concentrations of $\mathrm{Cd}$ and $\mathrm{Hg}$ in their tissues (Julshamn et al. 1987, Caurant et al. 1994, Gallien et al. 2001, Olsen et al. 2003). Marine mammals are currently considered useful bioindicators of trace element contamination in the environment because of their high trophic level and their wide distribution. Differences in trace element concentrations between individuals from different areas may be due to different exposures through food rather than to metabolic differences. Consequently, the continued release of toxic metals such as $\mathrm{Cd}$ or $\mathrm{Hg}$ into the environment is of particular concern in these areas.

\section{Toxicological aspects}

Processing of trace elements depends on the individual regulation and/or detoxification mechanisms of storage or excretion in the organism concerned. Thus extremely high levels of toxic $\mathrm{Hg}$ and $\mathrm{Cd}$ in mature grey seals may result in cellular and physiological damage to the storage organs, whereas renal dysfunction would be expected at Cd concentrations $>50 \mu \mathrm{g}$ $\mathrm{g}^{-1} \mathrm{WW}$ in humans (Elinder \& Järup 1996). In the present study, Cd concentrations in the kidney of mature grey seals were close to that threshold value (36.3 \pm $\left.28.8 \mu^{-1} \mathrm{~g}^{-1} \mathrm{WW}\right)$ with concentrations in the oldest females exceeding it by far (up to $155 \mu \mathrm{g} \mathrm{g}^{-1} \mathrm{WW}_{\text {; }}$ Table 2). Furthermore, most mature grey seals in this study contained $\mathrm{Hg}$ levels exceeding the threshold of $60 \mathrm{\mu g} \mathrm{g}^{-1}$ for liver damage in mammals (AMAP 1998). Nevertheless, their body mass and blubber thickness (Table 1) indicated that these seals were in good health, strongly suggesting that grey seals in the Faroe
Islands have developed a very efficient detoxification process that allows them to process high $\mathrm{Cd}$ and $\mathrm{Hg}$ concentrations in their tissues.

The liver and kidney of grey seals have been reported to contained high levels of metallothionein, which could trap toxic metals such as Cd (Olafson \& Thompson 1974, Teigen et al. 1999). The primary role of metallothionein is to bind essential metals such as $\mathrm{Cu}$ and $\mathrm{Zn}$ and to serve as an intracellular protein in metal homeostasis (Vallee 1991). However, Cd shows a great affinity for metallothionein, leading to competition with $\mathrm{Zn}$ for binding sites and to a reduction of the toxic effects of Cd (Tsalev \& Zaprianov 1983). Thus, displaced Zn would induce metallothionein synthesis, increasing the number of binding sites within the renal cells. If this hypothesis is true, then $\mathrm{Cd}$ and $\mathrm{Zn}$ would be accumulated simultaneously. Significant correlation between Cd and Zn (Fig. 4) in the kidney of grey seals from the Faroe Islands strongly suggests an effective detoxification process of $\mathrm{Cd}$ involving metallothionein in this organ.

In the grey seal liver, $\mathrm{Hg}$ concentrations were strongly positively correlated with Se during the life span (Fig. 5). Se has been reported to provide some protection against $\mathrm{Hg}$ toxicity, apparently preventing hepatic accumulation of this element by formation of mercuric selenide (HgSe) granules (Pelletier 1985, Cuvin-Aralar \& Furness 1991, Nigro \& Leonzio 1996). HgSe granules (tiemannite) have been identified in the liver of seabirds, marine mammals and humans (Martoja \& Berry 1980, Pelletier 1985, Hansen et al. 1989, Nigro \& Leonzio 1996). Moreover, many studies have reported $\mathrm{Hg}$ and $\mathrm{Se}$ to be correlated in a molar ratio of 1:1, as in HgSe (e.g. Koeman et al. 1973, Nielsen \& Dietz 1990, Wagemann et al. 1998). The molar ratio of $\mathrm{Hg}$ :Se in the liver of grey seals from the Faroe Islands was $~ 1$ (Fig. 5), strongly suggesting the presence of tiemannite granules as a result of coprecipitation of $\mathrm{Hg}$ with Se. A 1:1 molar ratio between hepatic $\mathrm{Hg}$ and $\mathrm{Se}$ was found in mature males and females, which displayed the same kinetics of accumulation with age, indicating a similar detoxification process of $\mathrm{Hg}$ in the liver in both sexes. This also suggests that pregnancy and lactation are not efficient processes of heavy metal elimination in females. Moreover, the annual moult, which probably results in the elimination of some $\mathrm{Hg}$, is not sufficient to counteract a high assimilation of $\mathrm{Hg}$.

\section{Conclusion}

Grey seals from the Faroe Islands had very high $\mathrm{Cd}$ and $\mathrm{Hg}$ concentrations in their tissues, much higher than in other grey seal populations. The concentrations in the oldest individuals were clearly higher than the 
toxic threshold levels comprising a threat to their health. However, very efficient detoxification processes, involving metallothionein protein and co-precipitation of $\mathrm{Hg}$ with $\mathrm{Se}$, probably account for the good condition of the analysed seals. The present results reveal that the Faroe Islands also display the $\mathrm{Cd}$ 'abnormality' previously reported for polar oceans. Finally, very high $\mathrm{Cd}$ contents of the tissue indicate important changes in the diet of the seals during the course of the year. Hence, seals may also feed on cephalopods during some months, accounting for the high $\mathrm{Cd}$ concentrations in the oldest individuals.

Acknowledgements. We are grateful to K.A. Fagerheim, Institute of Marine Research, Bergen, for age determination of the seals and to I. Gallien and T. Guyot, University of La Rochelle, for technical assistance. This work was supported financially by the Regional Council of Poitou-Charentes and Rhodia.

\section{LITERATURE CITED}

Aguilar A, Borrell A, Pastor T (1999) Biological factors affecting variability of persistent pollutant levels in cetaceans. In: Reijnders PJH, Aguilar A, Donovan GP (eds) Chemical pollutants and cetaceans. J Cetacean Res Manag Spec Issue 1:83-116

AMAP (Arctic Monitoring and Assessment Programme) (1998) AMAP assessment report: arctic pollution issues, Chapter 7: Heavy metals. Arctic Monitoring and Assessment Programme, Oslo

Bargagli R, Nelli L, Ancora S, Focardi S (1996) Elevated cadmium accumulation in marine organisms from Terra Nova Bay (Antarctica). Polar Biol 16:513-520

Bustamante P (1998) Etude des processus de bioaccumulation et de détoxication d'éléments traces (métaux lourds et terres rares) chez les mollusques céphalopodes et bivalves pectinidés. Implication de leur biodisponibilité pour le transfert vers les prédateurs. $\mathrm{PhD}$ thesis, University of La Rochelle

Bustamante P, Caurant F, Fowler SW, Miramand P (1998a) Cephalopods as a vector for the transfer of cadmium to top marine predators in the north-east Atlantic Ocean. Sci Total Environ 220:71-80

Bustamante P, Chérel Y, Caurant F, Miramand P (1998b) Cadmium, copper and zinc in octopuses from Kerguelen Islands, Southern Indian Ocean. Polar Biol 19:264-271

Bustamante P, Bocher P, Chérel Y, Miramand P, Caurant F (2003) Distribution of trace elements in the tissues of benthic and pelagic fish from the Kerguelen Islands. Sci Total Environ 313:25-39

Caurant F, Amiard-Triquet C (1995) Cadmium contamination in pilot whales Globicephala melas: source and potential hazard to the species. Mar Pollut Bull 30:207-210

Caurant F, Amiard JC, Amiard-Triquet C, Sauriau PG (1994) Ecological and biological factors controlling the concentrations of trace elements ( $\mathrm{As}, \mathrm{Cd}, \mathrm{Cu}, \mathrm{Hg}, \mathrm{Se}, \mathrm{Zn})$ in delphinids Globicephala melas from the North Atlantic Ocean. Mar Ecol Prog Ser 103:207-219

Coquery M, Azemard S, de Mora SJ (2000) World wide intercomparison exercise for the determination of trace elements and methylmercury in estuarine sediment sample IAEA-405. IAEA Rep AL/127, MEL/70
Cuvin-Aralar MLA, Furness RW (1991) Mercury and selenium interactions: a review. Ecotoxicol Environ Saf 21: 348-364

Dam M (2000) Integrated ecological monitoring in the coastal zone; environmental pollutants, Report no. 2000:2, Food and Environmental Agency of the Faroe Islands

Dam M (2001) Analyses of mercury and organochlorines in individual marine mammals from the Faroe Islands. Fróðskaparrit 48:145-174

Das K, Debacker V, Bouquegneau JM (2000) Metallothioneins in marine mammals. Cell Molec Biol (Noisyle-Grand) 46:283-294

de Moreno JEA, Gerpe MS, Moreno VJ, Vodopivez C (1997) Heavy metals in Antarctic organisms. Polar Biol 17: 131-140

Dietz R, Riget F, Johansen P (1996) Lead, cadmium, mercury and selenium in Greenland marine mammals. Sci Total Environ 186:67-93

Elinder CG, Järup L (1996) Cd exposure and health risks: recent findings. Ambio 25:370-373

Fant ML, Nyman M, Helle E, Rudbäck (2001) Mercury, cadmium, lead and selenium in ringed seals (Phoca hispida) from the Baltic Sea and from Svalbard. Environ Pollut 111: 493-501

Frank A, Galgan V, Roos A, Olsson M, Peterson LR, Bignert A (1992) Metal concentrations in seals from Swedish waters. Ambio 21:529-538

Friberg L, Piscator M, Nordberg GF, Kjellström T (1974) Cadmium in the environment, 2nd edn. CRC Press, Cleveland, $\mathrm{OH}$

Gallien I, Caurant F, Bordes M, Bustamante P, Miramand P, Fernandez B, Quellard N, Babin P (2001) Cadmiumcontaining granules in kidney tissue of the Atlantic whitesided dolphin (Lagenorhyncus acutus) off the Faroe Islands. Comp Biochem Physiol C 130:389-395

Hammond PS, Hall AJ, Prime JH (1994) The diet of grey seals in the Inner and Outer Hebrides. J Appl Ecol 31:737-746

Hansen JC, Reske-Nielsen E, Thorlacius-Ussing O, Rungby J, Danscher G (1989) Distribution of dietary mercury in a dog. Quantification and localisation of total mercury in central and nervous system. Sci Total Environ 78:23-43

Julshamn K, Grahl-Nielsen O (2000) Trace element levels in harp seal (Pagophilus groenlandicus) and hooded seal (Cystophora cristata) from the Greenland Sea. A multivariate approach. Sci Total Environ 250:123-133

Julshamn K, Andersen A, Ringoal O, Moekore J (1987) Trace element intake in the Faroe Islands. I. Element levels in edible parts of pilot whales (Globicephala meleanus). Sci Total Environ 65:53-62

Koeman JH, Peeters WHM, Koudstaal-Hoi CHM, Tjioe PS, de Goeij JJM (1973) Mercury-selenium correlation in marine mammals. Nature 245:385-386

Law R (1996) Metals in marine mammals. In: Beyer N, Heinz G, Redmond-Norwood A (eds) Environmental contaminants in wildlife. SETAC Special Publications Series, CRC Press, Boca Raton, FL, p 357-376

Law RJ, Jones BR, Baker JR, Kennedy S, Milnes R, Morris RJ (1992) Trace metals in the livers of marine mammals from the Welsh coast and the Irish Sea. Mar Pollut Bull 24: 296-304

Law RJ, Blake SJ, Jones BR, Rogan E (1998) Organotin compounds in liver tissue of harbour porpoises (Phocoena phocoena) and grey seals (Halichoerus grypus) from the coastal waters of England and Wales. Mar Pollut Bull 36:241-247

Law RJ, Bennett ME, Blake SJ, Allchin CR, Jones BR, Spurrier CJH (2001) Metals and organochlorines in pelagic cetaceans stranded on the coasts of England and Wales. 
Mar Pollut Bull 42:522-526

Mackey EA, Demilralp R, Becker PR, Greenberg RR, Koster BJ, Wise SA (1995) Trace element concentrations in cetacean liver tissues archived in the National Marine Mammal Tissue Bank. Sci Total Environ 175:25-41

Mart L, Nürnberg HW (1984) Trace metal levels in the eastern Arctic Ocean. Sci Total Environ 39:1-14

Martoja R, Berry JP (1980) Identification of tiemannite as a probable product of demethylation of mercury by selenium in cetaceans. Vie Milieu 30:7-10

Mikkelsen B, Haug T, Nilssen K T (2002) Summer diet of grey seals (Halichoerus grypus) in Faroese waters. Sarsia 87: 462-471

Morris RJ, Law RJ, Allchin CR, Kelly CA, Fileman CF (1989) Metals and organochlorines in dolphins and porpoises of Cardigan Bay, West Wales. Mar Pollut Bull 20:512-523

Muir DCG, Wagemann R, Hargrave BT, Thomas DJ, Peakall DB, Norstrom RJ (1992) Arctic marine ecosystem contamination. Sci Total Environ 122:75-134

Nielsen CO, Dietz R (1990) Distributional pattern of zinc, cadmium, mercury, and selenium in livers of hooded seals (Cystophora cristata). Biol Trace Elem Res 24:61-71

Nigro M, Leonzio C (1996) Intracellular storage of mercury and selenium in different marine vertebrates. Mar Ecol Prog Ser 135:137-143

Nogawa K (1984) Cadmium. In: Nriagu JO (ed) Changing metal cycles and human health. Springer-Verlag, Berlin, p 275-284

Nyman M, Koistinen J, Fant ML, Vartiainen T, Helle E (2002) Current levels of DDT, PCB and trace elements in the Baltic ringed seals 2 (Phoca hispida baltica) and grey seals (Halichoerus grypus). Environ Pollut 119:399-412

Olafson RW, Thompson JAJ (1974) Isolation of heavy metal binding proteins from marine vertebrates. Mar Biol 28: 83-86

Olsen J, Hoydal K, Dam M (2003) AMAP Faroe Islands 1999-2001 Heavy metals. In: Hoydal K, Dam M (eds) AMAP Faroe Islands phase II: environment. Ministry of Environment, Copenhagen

Pelletier E (1985) Mercury-selenium interactions in aquatic organisms: a review. Mar Environ Res 18:111-132

Petri G, Zauke GP (1993) Trace metal in the crustaceans in the Antarctic Ocean. Ambio 22:529-536

Pierce GJ, Boyle PR, Thompson PM (1990) Diet selection by

Editorial responsibility: Otto Kinne (Editor),

Oldendorf/Luhe, Germany seals. In: Barnes M, Gibson RN (eds) Trophic relationship in the marine environment. Proc 24th Eur Mar Biol Symp. Aberdeen University Press, Aberdeen, p 222-238

Pierce GJ, Miller A, Thompson PM, Hislop JRG (1991) Prey remains in grey seal (Halichoerus grypus) faeces from Morey Firth, north-east Scotland. J Zool 224:337-341

Ryg M, Øritsland NA (1991) Estimates of energy expenditure and energy consumption of ringed seal (Phoca hispida) throughout the year. Polar Res 10:595-601

Skaare JU, Markussen NH, Norheim G, Haugen S, Holt G (1990) Levels of polychlorinated biphenyls, organochlorine pesticides, mercury, cadmium, copper, selenium, arsenic and zinc in the harbour seal, Phoca vitulina, in Norwegian waters. Environ Pollut 66:309-324

Teigen S, Andersen R, Daae HL, Skaare JU (1999) Heavy metal content in liver and kidneys of grey seals (Halichoerus grypus) in various life stages correlated with metallothionein levels: some metal-biding characteristics of this protein. Environ Toxicol Chem 18:2364-2369

Tsalev DL, Zaprianov ZK (1983) Atomic absorption spectrometry in occupational and environmental health practice. CRC Press, Boca Raton, FL

Vallee BL (1991) Introduction to metallothionein. In: Riordan JF, Vallee BL (eds) Metallobiochemistry, metallothionein and related molecules, Vol 205, Methods in enzymology. Academic Press, San Diego, p 3-7

Wagemann R, Stewart REA, Lockhart WL, Stewart BE (1988) Trace metals and methylmercury: associations and transfer in harp seal (Phoca groenlandica) mothers and pups. Mar Mamm Sci 4:339-355

Wagemann R, Innes S, Richard PR (1996) Overview and regional and temporal differences of heavy metals in Arctic whales and ringed seals in the Canadian Arctic. Sci Total Environ 186:41-66

Wagemann R, Trebacz E, Boila G, Lockhart WL (1998) Methylmercury and total mercury in tissues of arctic marine mammals. Sci Total Environ 218:19-31

Watanabe I, Tanabe S, Amano M, Miyazaki N, Petrov EA, Tatsukawa R (1998) Age-dependent accumulation of heavy metals in Baikal seal (Phoca sibirica) from the Lake Baikal. Arch Environ Contam Toxicol 35:518-526

Zauke GP, Savinov VM, Ritterhoff J, Savinova T (1999) Heavy metals in fish from the Barents Sea (summer 1994). Sci Total Environ 227:161-173

Submitted: June 5, 2003; Accepted: September 30, 2003 Proofs received from author(s): February 9, 2004 